\title{
Online incivility in times of Covid-19: Social disunity and misperceptions of tourism industry in Poland
}

\author{
Monika KOPYTOWSKA ${ }^{1}$ and Radosław KRAKOWIAK ${ }^{2}$ \\ ${ }^{1}$ University of Lodz \\ Lodz, Poland \\ ${ }^{2}$ Impuls Travel \\ Warsaw, Poland
}

\begin{abstract}
Lockdowns and other counter-measures introduced by governments around the globe in the aftermath of the outbreak of coronavirus dealt a serious blow to tourism and the hospitality industry. Faced with bankruptcy and closure, tourism-related businesses raised the alarm and called for government support, which in turn triggered numerous comments from online audiences. Focusing on such online discourses and the incivility they abound with, the present article aims to address various aspects of the interface between the crisis, online communication and social polarization, as well as the constitutive and constituted nature of discourse. We bring under scrutiny the response of the online public to appeals from the tourism industry, working on the assumption that these Internet comments, in terms of content and form, have been considerably shaped by three factors, namely (1) public perception of the tourism industry, (2) culture-related emotionality patterns, as well as (3) techno-discursive design and the resulting dynamics of communication within cyberspace. Adopting the Media Proximization Approach (MPA), together with the CDA perspective on discourse and representation, and drawing on insights from studies on online communication we analyze and discuss the corpus of online comments (53,043 words) following 21 articles on the crisis within the tourism industry in Poland published between 6 March and 23 June 2020. Our findings show that the response of the online public, which is predominantly negative and at times hostile, reflects the socio-political polarization in Poland, enhanced by the sense of threat to life and health as well as the scarcity of resources. Cyberspace and its technological affordances considerably affect solidarity and disunity dynamics through representational and interpersonal proximization, enabling creation and perpetuation of stereotypes along with values and emotions. Acting as proximization triggers, nomination, predication and argumentation strategies both reflect and shape knowledge and axiological preferences, which constitute an integral part of the construction of social reality.
\end{abstract}

Keywords: online discourse, online incivility, cyberspace, Media Proximization Approach, COVID-19, tourism industry

\section{For citation:}

Kopytowska, Monica \& Radosław Krakowiak. 2020. Online incivility in times of Covid-19: Social disunity and misperceptions of tourism industry in Poland. Russian Journal of Linguistics 24 (4). 743-773. DOI: 10.22363/2687-0088-2020-24-4-743-773 
Научная статья

\title{
Невежливость в интернете на фоне Covid-19: социальная разобщенность и неверные представления о туристической индустрии в Польше

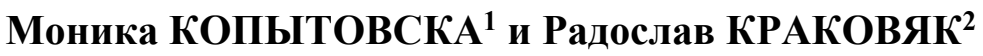

\author{
${ }^{1}$ Лодзинский университет \\ Лодзь, Польша \\ ${ }^{2}$ Туристическое агентство Impuls Travel \\ Варшава, Польша
}

\begin{abstract}
Аннотация
Самоизоляция и иные ограничительные меры, введенные по всему миру после вспышки коронавируса, нанесли серьезный удар по индустрии туризма и гостиничному бизнесу. Туристические компании, столкнувшиеся с банкротством и последующим закрытием, выразили обеспокоенность и призвали власти оказать им поддержку, что, в свою очередь, вызвало многочисленные комментарии в сети. В данной статье анализируются подобного рода онлайн-дискурсы и многочисленные проявления невежливости, рассматриваются различные аспекты взаимосвязи между кризисом, онлайн-коммуникацией и социальной поляризацией, а также между конститутивной и конституируемой природой дискурса. Мы внимательно изучили реакцию онлайн-аудитории на обращения туристической индустрии исходя из предположения, что эти интернет-комментарии с точки зрения формы и содержания в значительной степени сформированы тремя факторами, а именно (1) общественным восприятием туристической индустрии, (2) культурно-эмоциональными особенностями, а также (3) технодискурсивным дизайном и соответствующей динамикой коммуникации в киберпространстве. Опираясь на концепцию проксимизации в СМИ, положения критического дискурсанализа и результаты исследований онлайн-коммуникации, мы проанализировали корпус онлайн-комментариев, состоящий из 53043 слов, и 21 статью о кризисе туристической индустрии Польши за период с 6 марта по 23 июня 2020 года. Наши результаты показали, что реакция онлайн-общественности, которая является преимущественно негативной, а иногда и враждебной, отражает социально-политическую поляризацию в Польше, усиленную ощущением угрозы жизни и здоровью, а также нехваткой ресурсов. Киберпространство и его технологические возможности существенно влияют на динамику как солидарности, так и разобщенности через репрезентативную и межличностную близость, позволяющую создавать и закреплять стереотипы наряду с ценностями и эмоциями. Выступая в качестве инструментов проксимизации, стратегии номинации, предикации и аргументации отражают и формируют знания и аксиологические предпочтения, которые играют важную роль в конструировании социальной реальности.

Ключевые слова: интернет-дискурс, невежливость в интернете, киберпространство, концеепии проксимизациии в СМИ, СОVID-19, туристическая индустрия
\end{abstract}

\section{Для цитирования:}

Kopytowska M., Krakowiak R. Online incivility in times of Covid-19: Social disunity and misperceptions of tourism industry in Poland. Russian Journal of Linguistics. 2020. Vol. 24. № 4. P. 743-773. DOI: 10.22363/2687-0088-2020-24-4-743-773

\section{Introduction}

The outbreak of coronavirus disease (COVID-19) has affected the world like nothing else in recent history, triggering serious economic crises around the globe 
and significantly transforming transport and communication dynamics in all possible respects. Lockdowns and related restrictions have put a strain on one of the basic human needs, "compulsion of proximity" (Boden and Molotch 1994: 258, 277 ) or the need to achieve a state of co-presence (Kopytowska 2015a: 138). In view of closed borders, travel restrictions, cancellation of flights and public events, not to mention home quarantine and emphasis on social distancing, Urry's (2002) observation that people aim for proximity within three dimensions - with other people in face-to-face interactions, with unique locations in face-to-place interactions, and with special events in face-to-moment interactions - has acquired a new meaning. And, so have "mediated proximity and co-presence".

The present article aims to address various aspects of the interface between the pandemic triggered crisis, social (dis)unity and online communication. Specifically, it focuses on online discourses concerning the critical situation of the tourism industry in Poland and on public response to calls for government financial help coming from that sector. This response - overwhelmingly hostile and negative has, as will be demonstrated, three underlying causes: (1) public perception of the tourism industry and professionals working in it, (2) culture-related emotionality patterns characteristic of Polish people, and (3) "the techno-discursive design" of online media (KhosraviNik 2014, 2017b, 2018) along with communicative dynamics within cyberspace. These three focal points entail bringing in a number of concepts, assumptions and hypotheses from both Critical Discourse Studies and research on online communication and identity, in particular in times of threat and crisis. The Media Proximization Approach (Kopytowska 2013, 2015a, 2015b, 2015c, 2018a, 2018b, forthcoming) with notions of proximity and distance at its core will also be adopted here to explicate online incivility, along with stereotyping and discursive construction of us vs. them. Following Fairclough and Wodak (1997: 273), we work on the assumption that three broad domains of social life, namely representations of the world, social relations between people, and personal identities, are constituted discursively. In our case this discursive construction will concern the crisis related to the Covid-19 pandemic, professional identities of tourism industry employees and how they are perceived by others, as well as the process of social polarization in the event of health and economic threat.

The tourism industry has been chosen as our focus for several reasons. Firstly, it is the sector which has been most seriously affected by the pandemic along with the resultant lockdowns and travel restrictions. Secondly, despite the fact that the impact of Covid-19 on this industry has been discussed in the recent literature, there are no studies which would address the question of how this particular sector is perceived by the public and represented in online discourses. While interactions with tourism professionals or tourism related discourses such as advertising, reviews, etc. have been analyzed within Critical Discourse Studies or pragmatics, discursive representation of tourism professionals has not been the subject of scholarly attention. The present study fills in this gap by identifying patterns of, and motivations behind online incivility directed at the tourism industry professionals 
and explaining hostility towards them in the context of the Polish socio-political reality and culture-related "emotionality patterns" (Lewandowska-Tomaszczyk 2013, 2017c, 2020).

Data-wise, we will examine the corpora comprising comments following online articles on the crisis within the tourism industry in Poland published between 6 March and 23 June 2020. The analysis is mostly qualitative in nature, though Sketch Engine was used to compile and annotate the corpus and its concordance tool was used to analyze selected lemmas in relation to their immediate context.

\section{Cyberspace, proximization and online incivility}

"Technologies of the participatory web" (KhosraviNik and Unger 2015) have changed both the process of communication and those who participate in it. As posited by the Media Proximization Approach (MPA) "distance" in all its dimensions, along with "distance-related operations" have been at the core of this process of transformation (Kopytowska 2013, forthcoming). Stemming from Chilton's Discourse Space Theory (DST) $(2004,2005,2010$, Deictic Space Theory in 2014) and Cap's $(2006,2008,2010,2013,2017)$ STA model, MPA shares their assumption that distance-related operations, which consist in bringing closer (proximizing) selected aspects of reality, are likely to affect the perception of the audience members. However, while acknowledging the role of the performative potential, of language in distance reduction, MPA argues that proximization not only between selected aspects of reality and the audience (representational dimension) but also between members of the audience (interpersonal dimension) is possible thanks to "technological affordances" (Hutchby, 2001) of the media (Kopytowska forthcoming). Inextricably connected with "communicative deterritorialization" (Hepp 2013: 108), the cognitive and discursive nature of the proximization process enables both co-presence and mediated experience (Kopytowska 2013, 2015a, 2015b, 2015c, 2018a, 2018b), satisfying in this way the already mentioned human "compulsion for proximity" (Boden and Molotch 1994: 258, 277).

Assuming the performative potential of language and its role in assigning "status functions" and "deontic powers" (Searle 1995, 2006, 2010), along with the constitutive potential of discourse (Fairclough and Wodak 1997), MPA posits that media affordances and "distance work" enabled by them play a crucial role in all these processes. Language itself has the "capacity to transcend the "here and now" (Berger and Luckmann 1991/1966: 40), to induce presence of "a variety of objects that are spatially, temporally and socially absent" (1991/1966: 64), but with the technological affordances of the media individuals can "access" other individuals, places or events out there in the world. Not only can these "accessed" entities be spatially distant (spatial proximization), but they can also be proximized from the past or from the future (temporal proximization). Proximization can thus involve bringing closer (to media users) various aspects of reality (representational dimension of proximization), 
but also, thanks to "the techno-discursive design" (KhosraviNik 2014, 2017a, 2017b, 2018) of the online media, engaging these users in interaction with other users (interpersonal dimension of proximization).

Media users' knowledge concerning the events and phenomena referred to in online discourse can be discussed in terms of epistemic distance. The less people know about something and the less they understand it, the greater the distance. To reduce it, one will have to refer to his or her (or other users') previous experience or knowledge of similar events. Generalizations, stereotypes, and simplifications on the one hand, and particular illustrative examples on the other will enhance epistemic proximization. In the case of digital communication, anonymity and the resulting lack of accountability for one's words, will make people more likely to rely on mental shortcuts and simplistic judgements (Tetlock 1983), which, we argue, will have a cumulative effect.

Axiological distance, concerning differences in cultural values, beliefs and practices, involves the opposition of "us" versus "them", or "us" versus the "Other". Such opposition will gain particular prominence in view of threat or scarcity of resources (Duckitt 2006), which is what we call "axiological urgency" (Kopytowska 2015b, forthcoming). Lewandowska-Tomaszczyk (2020: 263) links hatred to "value and belief conflict, which is rooted in situations perceived by the individuals involved as disadvantageous to their own wellbeing", pointing to either "scarcity of certain resources or a threat concerning the users' status and position". Within cyberspace, as posited by the Social Identity Model of Deindividuation Effects and related approaches, the perceived sense of anonymity is likely enhanced in-group identity among the users, making them more prone to stereotyping and dismissing opinions of those they consider members of the out-group (Lea and Spears 1991, Postmes, Spears and Lea 2002). Granted that the Internet facilitates and enhances the creation of "filter bubbles and echo chambers" (KhosraviNik 2017a: 64), where similar attitudes, ideas and beliefs are confirmed and amplified, "axiological preferences" (Kopytowska forthcoming) will be both the point of departure and the factor shaping the dynamics of online interactions.

Being about the affective involvement of media users, emotional distance is highly dependent on all the other distance dimensions. In the case of online discourses, both interactivity and anonymity will considerably affect the process of distance reduction here (emotional proximization). Tadic et al. (2013) write about "bursts of emotional messages that involve many users", while others discuss the affective potential of cyberspace, with anonymity as a key factor, in the context of online incivility (Halpern and Gibbs 2013, Lewandowska-Tomaszczyk, 2015, 2017, 2020, KhosraviNik and Esposito 2018, Kopytowska, Grabowski and Woźniak 2017, Kopytowska, Woźniak Grabowski 2017, Kopytowska forthcoming). Following Tice et al. (2001), Lewandowska-Tomaszczyk (2017c: 350) points to a correlation between intense negative emotional states and self-control. Additionally, states of anger and disgust, she observes (ibid.), decrease the processing depth and increase referencing to stereotypes. In this way we can see 
that not only lack of accountability (Santana 2014, Hardaker and McGlashan 2015: 82 ), but also negative emotions have impact on the proliferation of stereotypical and simplistic judgements (Lewandowska-Tomaszczyk 2017c, 2020). Likewise Kopytowska, Grabowski and Woźniak (2017: 68), we argue that "discursive spiral of hate" is the consequence of not only anonymity, but also interactivity patterns, both involving distance work (proximisation). Being anonymous, the perpetrator of online aggression can relieve frustrations and negative emotions. Importantly, he or she is often supported by others who join in with similar views, fears and ideologies (Kopytowska 2017).

In addition to the techno-discursive design of the media and technological affordances-related proximizing potential, there are cultural factors at play too. Research on cultural emotionality patterns in the context of digital communication by Lewandowska-Tomaszczyk (2017a, 2017b, 2017c, 2020), along with comparative studies on conceptualising and expressing emotions in different cultures by Lewandowska-Tomaszczyk and Wilson 2013, 2014, 2016) shed new light on the culture-emotionality-communication interface and the implications it has for online verbal aggression. Lewandowska-Tomaszczyk (2020: 255-256) points to the higher expressivity of emotion in Polish culture resulting in greater online incivility. She links it with "higher emotionality expressiveness index", observing that "the structure of argument in the Polish context typically exhibits very high emotionality, often leading to moral judgments of an antagonistic type, irrespective of the type of discourse" (2020: 268). What she also emphasizes, however, is the role of the socio-political context: "Polish history, with its experience of a long fight for independence against foreign occupying forces, conditions a more negative attitude, comprising stronger emotions of fear and distrust not only towards the 'Others', but also toward one another within the society. Today, hate speech is also a sign of current conflict escalation and radicalization of attitudes and behaviours, triggered by disgust and fear scenarios" (Lewandowska Tomaszczyk 2020: 285-286).

Indeed, antagonistic attitudes towards the "Others" can be traced back to events in the country's history, but also should be linked to increasing polarization of the society. Conceptualized predominantly as division between supporters of the Law and Justice Party (PiS) and the Civic Platform (PO) such social polarization has been successfully enhanced by the media and politicians on both sides of the political scene. What is relevant to our analysis is the fact that, on coming to power, the Law and Justice Party brought forth the notions of national pride, along with the role of tradition, values, religion, and, most importantly, focus on "ordinary Poles". This was captured very well by Beata Szydło, former Prime Minister of Poland who said: "We are a government that represents ordinary Poles. We are not a government of the elites and our main priority is ensuring that every citizen feels they are living a dignified life and have the right of self-determination". ${ }^{1}$ Such a juxtaposition

\footnotetext{
${ }^{1}$ https://www.premier.gov.pl/en/news/news/prime-minister-beata-szydlo-in-the-sejm-the-lawand-justice-government-is-a-government-of.html
} 
between "ordinary Poles" and "the elites", along with views and values attributed to both groups, made its way from political and media discourses to collective imagination and emotions.

Social disunity and strong emotional arousal had their manifestations in online discourses surrounding the 2015 refugee crisis (Kopytowska, Grabowski and Woźniak 2017, Kopytowska, Woźniak and Grabowski 2017). While at that time divisive fear was associated with the "Other" coming from the outside and perceived (and constructed by media and politicians) as posing a threat in both a symbolic and a physical sense (Baider and Kopytowska 2017, see also Cap 2018a, 2018b, Larina et al. 2019), in the case of Covid-19 it was anxiety due to health- and life-threatening pandemic, general uncertainty, and scarcity of resources that led to tensions and social divisions visible in our data.

\section{Tourism, media and COVID-19}

Nothing in the history of communication has shown the potential of proximization to the extent that online interactions within cyberspace do. During the time of the pandemic, it has enabled proximity with other people in mediated face-to-face interactions, but also proximity with events and with places, to recall Urry (2002) again. With its immediacy, intertextuality, connectivity and interactivity, the Internet made the experience of crossing time and space boundaries even easier.

But the interface of tourism and media started attracting scholarly attention much earlier. Already in 1985, linking "post-tourism" to mediated experience, Feifer saw post-tourist as a traveller who largely travels in front of the TV screen and through travel magazines, "consuming" places without being physically mobile. In her words, "[a]s the McLuhanesque global village of communications media gets bigger and more elaborate, the passive functions of tourism (i.e. seeing) can be performed right at home, with video, books, records, TV" (ibid.:269). Researchers have thus discussed the role of media, in particular new media, in transforming both travel practices and perceptions of "others" and tourist destinations. While Urry (1995: 166) pointed to the impact of "massive amounts of mobility" on social identities, Shakeela and Weaver (2014) argue that social media are revolutionizing the way in which destinations are being portrayed and perceived. In the words of Urry (1990: 100), "the typical tourist experience is...to see named scenes through a frame, such as the hotel window, the car windscreen or the window of the coach". Mass-mediated encounters, for example through the frames of social media, have added yet another dimension to this "tourist gaze" as defined by Urry (1990), bringing in new constitutive potential of both media representations and discursive practices. The social implications of the former, we argue, have been inextricably linked to changing dynamics within the latter. The growing number of prosumers of media images has vastly expanded the potential impact of media representations, in both qualitative and quantitative terms. 
Researchers have discussed representations of people, places and tourismrelated practices along with their social impact. These have been, for example, stereotypical representations of Japanese tourists (Beauregard 1999), representations of Indonesian rural destinations in Australian online and offline media (Murti 2020), British print media coverage of South Africa (Hammett 2014), social media users' representations of particular tourist destinations (Zhao et al. 2018), as well as re-conceptualisations of gambling tourism in Macau (O'Regan et al. 2019), Korean American community newspapers' representation of risks and benefits involved with medical tourism (Jun and Oh 2015), or even representations of "overtourism" in the online news media (Pasquinelli and Trunfio 2020). In the context of the Covid-19 pandemic the role of media has been discussed with respect to the impact of misleading media coverage on Chinese individuals and China, and possible implications for tourism marketing and tourist behaviour during times of crisis (Wen et al. 2020, see also Zhang and Xu 2020).

As already mentioned, however, representations of tourism industry professionals have not been the focus of attention. Yet, as we will attempt to demonstrate, these become particularly relevant when we look at online media discourses from the point of view of their socially constituted and constitutive nature. Not only do they reflect public perceptions of particular groups, problems, and phenomena, but they also contribute to shaping these perceptions further by perpetuating stereotypes and disseminating portrayals of, for example, these groups.

\section{Analysis}

\subsection{Background}

The Covid-19 pandemic and travel restrictions that came along with it have affected global tourism in multiple ways (Lew et al. 2020, Gursoy and Chi 2020). Authors have discussed the impact of Covid-19-induced change in touristic flows on countries' economies and natural environment (Dube et al. 2020, Lenzen et al. 2020). One of the consequences of this change in travel dynamics has been a greater orientation of tourism sectors towards local communities (Lapointe 2020, Tomassini and Cavagnaro 2020).

On $15^{\text {th }}$ March 2020, Polish international air passenger and rail connections were suspended. Temporary border controls were introduced at all Polish borders and only Polish citizens and workers were allowed to enter the country, with a fourteen-day quarantine period upon arrival. Public gatherings and events with more than fifty participants were banned. On $24^{\text {th }}$ March 2020, Polish Prime Minister announced the introduction of new restrictions, including a ban on movement and travel, which came into force one day later. Restrictions were lifted gradually starting with $20^{\text {th }}$ April 2020. On $31^{\text {st }}$ anti-crisis shield 1.0. was adopted by the Polish government and entered into force on the same day. Anti-crisis shield 2.0. and anti-crisis shield 3.0. entered into force on $18^{\text {th }}$ April and $16^{\text {th }}$ May 2020, respectively. A law concerning further amendments was passed on $19^{\text {th }}$ June 2020 
and entered into force on $24^{\text {th }}$ June 2020 . The main objective of these anti-crisis packages was the protection of employment and maintaining financial liquidity of companies. Relief for the tourism industry offered within these laws included the extension of the deadline for reimbursement of customer payments and opportunity for customers to use vouchers for the realization of a tourist event within a year of the day on which the event was to be cancelled due to the Covid-19 pandemic.

\subsection{Data and methodology}

To investigate incivility targeted at professionals from tourism industry in the context of Covid-19 pandemic we examined a corpus of online comments (53,043 words). The comments followed articles on the crisis within the tourism industry in Poland published online between $6^{\text {th }}$ March and $23^{\text {rd }}$ June 2020. We used Google search as well as in-built search engines on particular news websites in order to identify - by keying in the search word branża turystyczna 'tourism industry" and turystyka 'tourism'- and subsequently retrieve relevant articles. Only the articles discussing the situation in Poland in the context of crisis in this sector and only those followed by comments were selected. In this way we compiled a corpus of articles $(11,371)$ and comments $(53,043$ words). Both corpora were tagged and parsed using Sketch Grammar for Polish developed on the basis of the tagset of the IPI PAN Corpus of Polish implemented into the Sketch Engine software (Kilgarriff et al. 2014). The Sketch Engine Concordance and Word Sketch tools were used to analyze selected lemmas in relation to their immediate context. Using the Keywords tool and the corpus with articles as reference corpus we identified terms (multi-word items) in the corpus of the Internet users' comments. In this way we could see what was particularly salient in the latter corpus.

In order to identify perceptions of the tourism industry and professionals working in it among Internet users we identified referential, predicational and argumentation strategies. Since these are involved in the positive self- and negative other-representation (Reisigl and Wodak 2001: 44), we assumed that their function will be two-fold. Firstly, they will act as proximization triggers making certain aspects of discursively represented events or groups more salient. In this way they will both reflect and potentially shape public perceptions. Secondly, they will be conducive to online incivility due to their "emotive effects" (Hart 2010: 63).

Referential strategies, which are used to construct and represent social actors, consist in identifying persons and groups by naming them (Reisigl and Wodak 2001: 45). As our focus is incivility and negative representations leading to polarization, we will be particularly interested in derogatory terms and the use of deixis. Predicational strategies, aimed at labelling social actors "more or less positively or negatively, deprecatorily or appreciatively", involve "stereotypical, evaluative attributions of negative or positive traits in the linguistic form of implicit or explicit predicates" (ibid.). Such attributions are then justified through topoi "described as parts of argumentation that belong to the obligatory, either explicit or inferable, premises" (pp. 74-75). Several topoi will be relevant to our discussion. 
These include: the topos of advantage or usefulness ("if an action under a specific relevant point of view will be useful, then one should perform it"), the topos of uselessness/disadvantage ("if existing rullings do not help to reach the declared aims they have to be changed"), the topos of danger or topos of threat ("if there are specific dangers or threats, one should do something against them"), the topos of justice ("if persons/actions/situations are equal in specific respects, they should be treated/dealt with in the same way"), the topos of finances ("if a specific situation costs too much money or causes a loss of revenue, one should perform actions that diminish the costs or help to avoid the loss"), the topos of reality ("because reality is as it is, a specific action/decision should be performed/made"), and the topos of abuse ("if a right or an offer for help is abused, the right should be changed or the help should be withdrawn or measures against the abuse should be taken") (Reisigl and Wodak 2001: 75-80). From the perspective of MPA topoi will be particularly important as both triggers and effects of epistemic proximization (explaining why), and in consequence axiological and emotional proximization (moral/value judgements and emotions associated with these explanations). As already mentioned, in order to create a sense of axiological urgency, for example, one needs first to make more cognitively and effectively salient the notion of threat to or, at least, incompatibility with "our" values.

\subsection{Construction of crisis in tourism industry in the articles}

While the corpus of articles on the crisis in the tourism industry is not the main focus of our analysis, it seems relevant to see how the crisis in this particular sector is discursively constructed, especially in view of the fact that, as argued by Kopytowska (2013, 2015a, Kopytowska, Grabowski and Woźniak 2017) keywords and other discursive devices used by the authors of the articles are likely to act, partially at least, as proximization triggers, for the audience, making selected aspects of discursively represented problems, events or groups more salient and thus cognitively and affectively accessible.

Out of twenty-one headlines (see Appendix 1) twelve focus on crisis and losses in the tourism industry due to the coronavirus pandemic, using phrases like "crisis hits tourism", "losses in tourism", or "travel agencies on the brink of bankruptcy". To convey the seriousness of the situation a metaphor TOURISM IS A SICK PERSON is used in one of the headlines: Turystyka na OIOM-ie ('Tourism in ICU'). In the context of the pandemic the metaphor is likely to act as a strong epistemic and emotional proximization trigger, as also is phrase "crisis kills tourism" used in one of the headlines.

Seven headlines concern government help for tourism industry, focusing either on those who demand aid (e.g. Hotelarze z Kolobrzegu chca pomocy państwa ('Hotel owners from Kołobrzeg demand government aid'), or steps taken by the government, e.g. Sztab kryzysowy dla turystyki. Ministerstwo przygotowuje pakiet pomocy dla branży ('Emergency meeting for tourism. Ministry prepares aid package for industry'). Clients's cancellations [Biznes: Po stowach ministra 
wzrosta liczba rezygnacji z wyjazdów ['Business: After Minister's announcement the number of cancelled trips has increased']) and refunds for clients (Koronawirus. Możliwe zwroty za imprezy turystyczne ['Coronavirus. Possible refunds for tourist events']) are the subject of two headlines.

To create immediacy present tense is mostly used in the headlines. Future tense, however, is also applied when journalists are making speculations about the future, thus presenting certain events as imminent (temporal proximization). Numbers, usually related to losses, are meant to convey the scale of the crisis (epistemic proximization) but also have an effect on emotions (emotional proximization).

In the corpus with articles the concordance tool generated 74 concordances with the word turystyka ('tourism/tourism industry'), while the word sketch analysis for the lemma generated the following modifiers: krajowa ('domestic') (6), wyjazdowa ('outbound') (4), światowa ('world') (4), zagraniczna ('foreign') (3), polska ('Polish') (2), zorganizowana ('organized') (1), rejestrowana ('registered') (1), przyjazdowa ('inbound') (1), korporacyjna ('corporate') (1), biznesowa ('business') (1), europejska ('European') (1), and międzynarodowa ('international') (1). Individuals or entities from tourism industry cited or referred to include: branża turystyczna ('tourism industry') (113), hotelarze ('hotel owners') (9), biura podróży ('travel agencies') (57), przewodnicy ('tour guides') (9), piloci wycieczek ('tour leaders') (9), tour operatorzy ('tour operators') (2), przedsiębiorcy ('enterpreners') (28), przedsiębiorstwa transportowe ('transport companies) (9), Piotr Henicz, wicepreszes biura ITAKA, wiceprezes Polskiego Zwiazku Organizatorów Turystyki ('Piotr Henicz, vice president of ITAKA travel agency, vice president of the Polish Association of Tourism Organisers') (14). There is also a group of words related to a dramatic situation in the industry and measures taken: kryzys ('crisis') (45), straty ('losses') (38), upadek ('collapse') (5), bankructwo ('bankruptcy') (5), pomoc ('aid/help') (34), pakiet ('package') (6). These are important because they will act as triggers evoking particular responses, involving both judgements (axiological dimension), examples and stereotypes (epistemic dimension) used to substantiate these judgements and suggested measures and, in consequence, emotions (emotional dimension).

\subsection{Construction of tourism industry and professionals in the comments}

Multi-word analysis with article corpus as reference corpus provides some interesting insights as regards individuals, entities, and problems that became particularly salient in commenters' discourses. These include: biura podróży ('travel agencies') (34), nasze podatki ('our taxes') (6), ta branża ('this industry') (4), piloci wycieczek ('tour leaders') (9), swoje mercedesy ('their Mercedes cars) (3), szary obywatel ('average citizen') (4), zbiór truskawek ('collecting strawberries') (4). Among top 50 keywords, in turn, we will find: branża

\footnotetext{
${ }^{2}$ The number of occurrences of each word is provided in round brackets.
} 
('industry') (224), turyści ('tourists') (56), przedsiębiorcy ('enterpreners') (36), wycieczki ('trips'). The use of the Sketch Engine Concordance tool allowed us to examine the context in which these terms were used, which became a starting point for further qualitative analysis.

While comments are predominantly negative, and at times even hostile, in their assessment of the crisis, tourism industry workers as well as potential financial support, various arguments are provided by commenters and various images of tourism professionals are constructed.

The predominant image of work in the tourism industry is that the job is neither "real" nor "honest". A number of referential and predicational strategies are employed to undermine the professional status of this group, either explicitly or implicitly. Tourism professionals are referred to as cwaniacy ('clever dodgers') (11) and złodzieje ('thieves') (7):

(1) Tak jest pogonić cwaniakow. [Yes, let's do away with these clever dodgers.]

(2) Ustyszeli cwaniaki, że urlop w kraju, to podnieśli ceny. [Clever dodgers heard that holidays will be spent inside the country and they increased the prices.]

(3) Glównie to wyzyskiwacze, oszuści i ztodzieje. [These are mainly exploiters, frauds and thieves.]

(4) $W$ ogóle mi ich nie żal. Niech plajtuja jeden po drugim, ztodzieje. [I don't feel sorry for them at all. They, thieves, should go bankrupt one by one.]

What they do is implicitly put in opposition to a job considered the "proper" job. This is achieved by the verb weźcie się do ('get [a job]') in the imperative mood used with nominal phrases including such adjectival modifiers as normalna ('normal') (5), uczciwa ('honest') (4), konkretna ('meaningful') (1):

(5) Ja też bym k.... chciał żyć cudzym kosztem, weźcie się do konkretnej pracy i podejmujcie pracę która jest ludziom potrzebna do przeżycia. [F..., I'd also want to live at somebody else's expense, get a meaningful job, a job that people need to survive.]

(6) 1000 przewodników w Krakowie ? Noo to już przesada... Weźcie się do uczciwej roboty a nie spacerować po mieście z wycieczkami za grube pieniadze. [1000 tour guides in Cracow? Come on... Get an honest job instead of walking around with groups and earning big money for it.]

(7) CZłowieku weź się do roboty normalnej a nie z lapami do Państwa, a jak byty zyski to oddawateś więcej Państwu? Nie. Więc teraz wiesz co masz robic. [Man, get a normal job instead of holding your hands out to the State, when you had profits did you give back more to the State? No. So now you know what to do.] 
The owners of travel agencies are explicitly or implicitly characterized as chciwi ('greedy') [8], a trait which is illustrated with various examples concerning investing money [8], earning good money [9], raising prices [10] and not saving money [11]. Clauses of purpose are used to attribute negative intentions and motives $[8,10]$.

(8) "Biura podróży prosza o pomoc." Teraz chca biura pomocy, chciwi właciciele biur podróży pokupili drogie autokary w leasingi żeby nie placić podatku dochodowego wykazywać straty a teraz utopili się we własnym $m o c z u$. ["Travel agencies are asking for help." Now the agencies want help, greedy owners of travel agencies leased expensive coaches to avoid paying income tax show losses and now they have drowned in their own urine.]

(9) W d... mam te placzę ze im się wycieczki nie sprzedają! Przyzwyczaili się do koszenia kasy latami a teraz pierwsi wyciagaja tape bo im nie idzie! Mi nikt nie pomaga gdy mam gorsze miesiace w biznesie. [I don't give a f... about their cries that their trips are not selling! They got used to making it big for years and now they are the first to hold out their hands when business isn't going too well! Nobody helps me when my business is down.]

(10) Nie należy wspierać tej branży szczególnie biur podroży. Proponuja zmiane terminu na jesień, ale za dopłata. Celowo podnosza cenę na jesień, aby trzeba pokryć doptatę. ONI NIE Zachowuja się uczciwie. [We should not support this industry in particular travel agencies. They suggest postponing the trip till autumn but at an extra cost. They intentionally raise autumn prices to make you pay extra. THEY DO NOT behave honestly.]

(11) Jak tupili turystów na każdym kroku to bylo dobrze? Mogli odktadać na gorsze czasy. [When they overcharged tourists on every occasion it was okey? They could have put the money aside for worse times.]

Work in the tourism industry is associated with earning good money, which is what evokes commenters' envy, anger and frustration. The topos of justice comes to the surface here with two sets of arguments. Firstly, everybody should be equal, which is understood as "should work equally hard and with similar effects" [9, 12]. This is visible in statements like "I am .... and so should X" or "X should experience what Y does". Secondly, if someone was in a more privileged position for years, they should be held accountable for that and they do not deserve any help now $[9,11]$.

(12) Jasne. A wcześniej obracali milionami. Jeśli tak im zle,zapraszam do magazynu za 2700 brutto jak wielu moich znajomych. [Sure. And earlier they made millions. If they feel that their situation is so bad, they are welcome to work in a warehouse for 2700 gross as many of my friends.]

As already mentioned, tourist professionals are perceived (and referred to) as thieves and frauds. Several different reasons are provided here including the high prices of tourist services, lack of receipts for certain services, clients' money lost 
due to travel agencies' bankruptcies, as well as dissatisfaction with the services provided.

(13) Branża turystyczna. Hahaha. Raczej brnza ZLODZIEJI! Żadnych paragonów nie wystawiaja, ceny kosmos dla milionerów. Żeby zwykty szary obywatel nie mógt pojechać nad morze czy w góry i pokazać kawałek Polski swojemu dziecku bo go nie stać. Co za absurd, że taniej jest 3 czy 4 tys $\mathrm{km} \mathrm{z}$ tad gdzie zawsze jest pogoda? Jesteście zlodziejami i tyle! Przestańcie płakać w końcu. Obniżcie ceny ro wszyscy przyjada! [Tourism industry. Hahaha. Rather the industry of thieves. They give no receipts, prices are exorbitant. How come that an average ordinary citizen cannot go to the seaside or to the mountains and show a piece of Poland to his child because he cannot afford it. It is absurd that it is cheaper 3 or 4 thousand kilometers away where there is always a good weather? You are thieves. Full stop. Stop crying. Lower the prices and people will come!]

(14) ... to nieroby naciagacze i oszusty, zbieraja kasa na wycieczki a potem sie okazało że nie oplacili Hotelu i nie optacili obiadków bo kasa znika kilka razy dio roku w tej branży !!! [These are slobs, tricksters and frauds, they take money for trips and then it turns out they haven't paid for the hotel and food because money disappears a few times per year in this industry!!!]

(15) nie żatuję ich, tak zwani touroperatorzy, wszelkie biura podróży z tymi wielkimi niemieckimi na czele to banda oszustów, nigdy rzeczywistość nie zgadza sie z tym co podaja na swoich stronach czy katalogach, w zesztym roku bytem na Krecie $w$ hotelu 5 stars, wszystko się zgadzało z wyjątkiem opisu plaży, miała być piaszczysta, była kamienista z takimi kamieniami w morzy przy brzegu, że mój 10 letni syn nie mógt sam pokonać tej rafy, żeby potem poptywać w morzu (a plywa dobrze) itd. to było z TUI, ostatni raz datem się nabrać. [I don't feel sorry for them, the so-called tour operators, any travel agencies including the big German ones are a pack of frauds, reality never matches what they put on their websites or in catalogues, last year I was in Crete in a 5 star hotel and everything was okey except the beach, it was supposed to be sandy and was pebbly instead with such stones in the sea and on the shore that my 10 year old son could not go over that reef to swim in the sea (and he swims well) etc. it was TUI, and the last time I had been fooled.]

(16) Przez kilka lat jeździtem nad morze i nigdy nie dostatem paragonu. Jesteście ZLODZIEJAMI!! Tak, niepłacenie podatków to jest złodziejstwo! Dlaczego to jest tolerowane? [For some years I used to go to the seaside and I never got a receipt. You are THIEVES!!! Yes, not paying taxes is thievery. Why is it tolerated?]

Several observations can be made in connection with the above examples [13-16]. Firstly, we have to do here with the fallacy of "hasty generalization" or secundum quid (Reisigl and Wodak 2001: 73), where personal experience with the provider of particular services becomes the basis for judgement concerning the whole industry resulting in the use of derogatory terms. Secondly, tourism industry professionals are blamed for high prices in the services which, in view of some 
commenters, an "average Polish citizen" cannot afford [13]. What already can be seen here is an implicit opposition between allegedly affluent tourism professionals and the rest of the society, illustrated with examples mentioning cars as status symbols $[18,19]$. Such status symbols stand metonymically for luxury and wealth attributed to this group (as already mentioned, "their Mercedes cars" was among multi-word terms salient in the corpus with comments). When juxtaposed with the image of holding out hands for financial help they evoke anger, envy and contempt. The latter is also visible in implicit questioning of the moral values of this group by associating it with moral laxity [18]. In [17], in turn, a strongly vulgar offensive word is used as part of referential and predicational strategies.

(17) Wyciaganie tap tlustych hotelarzy, sqrwysyny [Fat hotel owners are holding out their hands, motherfuckers.]

(18) Biedni hotelarze będa musieli sprzedawać swoje mercedesy klasy $\boldsymbol{S}$, porszafki, i inne fury, porzucić kochanki $\boldsymbol{i}$ kochanków bo trzeba będzie przycisnać pasa. [Poor hotel owners will have to sell their $\mathbf{S}$ class mercedes cars, Porsche and other cars, abandon their mistresses and lovers because they will need to cut back.]

(19) Znam tych z turystyki!! Byle agencja a pierwszy zakup to BMW X5 lub audi A6.Z zyskami to chyba się nie dzielili. [I know those form tourism industry!!! Any agency and its first purchase is BMW X5 or Audi A6. They didn't share their profits I suppose.]

Not only are the representatives of the tourism industry considered rich and undeservedly enjoying better social status than the rest of the society, but the perceived wealth and luxury they live in are attributed to "exploiting" tourists, something that is considered highly contemptible [20-24].

(20) branża turystyczna przez ostatnie lata zyla w luksusach dzięki turystom więc maja gdzieś ulokowane zyski, zamiast żebrać to trzeba uruchomić skarbonke na ten kwartat $i$ nie robić wstydu. [for the last years tourism industry lived in luxury thanks to tourists so they have their earnings put aside somewhere, instead of begging they should use their money box for this quarter and stop being embarrassing.]

(21) Wyją krezusi wypasieni na zdzieraniu skóry z rodaków [That's a cry of fat cats that got fat ripping the skin off their compatriots.]

(22) A jak branża turystyczna zarabiała krocie na nas, to byto cicho. Wcale ich teraz nie zatuje. [And when tourism industry earned money on us, they were quiet. I don't feel sorry for them at all now.]

(23) Przez te lata nachapali się - Maja mienia, samochody, domy majątki warte MILIONY - A CO MA POWIEDZIEĆ Robotnik, który stracit pracę a na utrzymaniu rodzina, dzieci - Nie ma czym zapłacić za Mieszkanie [For all those years they lined their pockets - they have property, cars, houses and fortunes worth MILLIONS - AND WHAT ABOUT a factory worker who lost his job, has a family and children to provide for - has no money to pay the rent.] 
(24) Winduja ceny z kosmosu a teraz chca leżeć i żeby im rząd dawat kasę. Macie milionów y na kontach a przecież nie chcieliście polskich rodzin tylko eeelllyty gościć to macie za karę dekoniunkture i tyle. [They gave exorbitant prices and now want to lie and get money from the government. You have millions in your accounts and you didn't want to host Polish families but elites so you have downturn in return.]

The "us" vs. "them" dichotomy is created here, not only by means of deixis ("us") but also by putting tourism professionals in opposition to other citizens. Another frequently used polarizing juxtaposition can be seen in [24], a juxtaposition between an average Polish family and the elites. While first used in 2006 with a pejorative meaning by Jarosław Kaczyński, the leader of the Law and Justice Party (PiS), within the rhetoric of "good change" developed since then "elites" have become the synonym of the enemy of political reforms introduced by this conservative party. According to Kłosińska and Rusinek (2019: 70-72) "elites" have been typically used with modifiers like "Brussels", "European" or "opposition" and thus portrayed as being against "real" Poles. As argued by these authors in times of "good change", that is the rule of Law and Justice party, among politicians of this party as well as those who support it the term acquired only negative connotations. Elites started to be seen as evil, corrupt and anti-Polish (ibid. 72). Associating the tourism industry with "elites" has its axiological consequences and acts as an axiological proximization trigger. Tourism professionals become part of the "them" group not deserving support from "us".

The parasite metaphor is used [25] to describe those employed in this sector along with other terms like "spongers" [26] and "exploiters" [27] appearing in the context of pleading for government help:

(25) wyjattkowo pasożytnicza i droga ta branża w Polsce. [Uniquely parasitic and expensive industry in Poland.]

(26) "Tarcza nie starcza"? Dostajecie kasę za nic i jeszcze wam mało ...DARMOZJADY. Szklarnie w Holandii, maliny $w$ Norwegii, budowy $w$ Austrii...czekają. Narzekacze pospolici!!!! [“Work package is not enough"? You are getting money for nothing and it is still not enough for you. ...SPONGERS. Greenhouses in the Netherlands, raspberries in Norway, construction sites in Austria... are waiting. You common grumblers!!!!]

(27) przez lata trzepali kase robiac majątki a teraz przez trzy miesiace nagle stracili wszystko pewne JEST CHCA WYDOIC KASE OD PAŃSTWA to cwani wyzyskiwacze korzystajac z koronowirusa!!!!!!!!!!!!!!!!!! [For years they earned big money making fortunes and now during three months they lost everything FOR SURE THEY WANT TO EXTORT MONEY FROM THE STATE these are cunning exploiters taking advantage of coronavirus !!!!!!!!!!!!!!!]

This kind of metaphor, aimed at degrading and dehumanising its target, has been, as argued by Musolff (2014), routinely used for the purpose of racial and socio-political stigmatization and legitimization of measures taken against a 
particular group, including that of annihilation. In this case it is used for polarization purposes, portraying the industry as harmful to the rest of the population in a situation in which the resources of the whole nation are scarce. The negative image is enhanced firstly by the already mentioned construction of opposition "us" vs "them" and, secondly, by attributing evil intentions [27]. In other words, not only did they get money for nothing (in contrast to others working hard) before the pandemic, but they also want to exploit the system at a time when the whole country is in a difficult situation. The topos of abuse emerges here to justify both hostility and objection to financial support. "Why should our taxes be used to help those who do not respect Polish people and exploit both their compatriots and the state?", seems to be the question underlaying commenters' outrage and refusal to help.

Tourism professionals are recommended to try other seasonal jobs abroad involving physical labour [26]. Work in supermarkets as a cashier is often referred to, considered to be an unskilled job which is hard and badly paid [28-30]. Commenters thus again question the "serious/real work" status of the tourism profession, which is additionally emphasized in example [30] by the phrase "You will have money from work":

(28) Na tych biznesmenów turystyki czekaja wolne posady od zaraz: jako kasierki/- rzy w Biedronie albo Stokrotce. [For these tourism businessmen there are vacancies to take immediately: as cashiers in Biedronka or Stokrotka. $]^{3}$

(29) W Biedronce ciagle przyjmuja kasjerów. [In Biedronka they are still employing cashiers.]

(30) Biedronki, lidle i inne markety spożywcze potrzebuja pracowników na już! Śmiało skoro brakuje pracy to do marketów na kasy i rozktadanie towaru. Kasa będzie z pracy. [Biedronka and Lidl and other grocery stores need employees now. So off you go if there is not enough work go to the stores to work as cashiers or to place goods on shelves. You will have money from work.]

Alternatively, other examples of physical work are given [31] ironically mentioning "suntan" associated with this group of professionals, or using change of state verbs to trigger the presupposition that this group has not really worked so far [32]:

(31) Branża turystyczna mile widziana przy pracach polowych, opalenizna gwarantowana. [Tourism professionals are welcome to work in the fields, tan guaranteed.]

(32) Zawiesić firmę $i$ do pracy się wziąć. [Suspend business and start working.]

${ }^{3}$ Biedronka is the largest Portuguese supermarket chain in Poland. Initially it targeted lower-income customers. In April 2004 a TV programme broadcast by TVN Uwaga revealed that its workers were not properly paid for working overtime, which started a series of court cases. 
As regards the argument about exploiting the system, commenters question pleas for government help by either challenging the professionalism of tourismrelated businesses [33,34] or referring to prices as an indicator of their income [31].

(33) 3 dni wystarczylo by byly "na skraju bankructwa"? A co to za ch... firmy?! [ 3 days were enough to put them "on the verge of bankruptcy"? What kind of s... companies are these?!]

(34) To w takim razie to nie biura podróży, a piramidy finansowe, skoro chwilowy brak klientów powoduje upadek. [Then these are not travel agencies but pyramid schemes, if a temporary lack of clients leads to their demise.]

(35) Niech biura turystyczne przestana plakać i nie prubuja naciagnać państwo na kasę. Gdyby faktycznie biura byly w kryzysie to obnizalyby ceny ofert turystycznych a te sa niezmiennie wysokie. Tak działa rynek, jest źle obniża się ceny. Czyli kryzys to bujda i pruba wyludzenia pieniędzy. [Travel agencies should stop crying and trying to extort money from the state. If indeed travel agencies were in crisis, they would be lowering prices and these are still high. This is how the market works, when the situation is bad, prices are lowered. So the crisis is a whopping lie and an attempt to extort money.]

In addition to the already mentioned topos of abuse other topoi are referred to in order to portray tourism industry's pleas for help as unsubstantiated. One of them is the topos of reality: the situation is as it is and one should accept it [36, 37].

(36) Och, straszne. Naprawde nie trzeba być wybitnym analitykiem, aby przewidzieć, że w razie epidemii, branże turystyczne będa mniej zarabiać lub tracić. Normalne ryzyko biznesowe. [Oh, how terrible. Really, you don't need to be an outstanding analyst to predict that in the case of epidemic tourism industry will earn less or lose money. It's the usual business risk.]

(37) To jest biznes, raz jest gorzej raz lepiej. Zawsze można się przebranżowić $i$ być elestycznym na rynku, a nie płakać. [This is business, there are ups and downs. You can always retrain and be flexible on the market instead of crying.]

More frequently, however, the topos of uselessness and topos of finances are employed to question the need for government help, or even the raison d' etre of such companies (34-36).

(38) taka branża jest nikomu do życia nie potrzebna, niech ida z torbami $i$ nie wyciagaja tap po pieniadze uczciwie pracujacych [nobody needs this industry, let them go broke so that they don't hold out their hands for the money of those who work honestly.]

(39) a co mnie to obchodzi jakaś branża turystyczna, to nie jet potrzebne do przeżycia. [I don't care about tourism industry, it is not necessary to survive.] 
(40) Drogi rządzie zero pomocy dla touroperatorów rynek sobie bez nich poradzi.Większość z nich to zwykte pasożyty żyjące z pośrednictwa nic nie wnoszace dla naszego kraju a wręcz przeciwnie $w$ dobie kryzysu pomaganie im tylko ostabi gospodarke bowiem wyprowadzi kapitat za granicę. [Dear government, no help for tour operators the market will manage without them. Most of them are ordinary parasites living off intermediary services and contributing nothing to our country, to the contrary, in time of crisis helping them will only weaken the economy as it will take the capital abroad.]

The topos of threat, acting as a strong trigger of emotional proximization can also be found in the comments. Tourism is presented as the cause of the current pandemic, which has two consequences. One of them is anger addressed at the perceived culprit. Secondly, what follows logically is that in order to avert (the continuity of) the threat, one has to eliminate the factors causing it, namely tourismrelated activities [41-44].

(41) A to nie przez turystykę tak się wirus rozprzestrzenit po ziemi? [And isn't it because of tourism that the virus spread all over the globe?]

(42) Turystyka to glówna przyczyna tak szybkiej ekspansji wirusa, dlatego już w styczniu powinna być zablokowana, ale chciwe rzady państw w obawie przed spadkiem dochodów nic nie robity, a teraz doprowadzili do dużo większych strat - ciekawe tylko kto za to odpowie po zakończeniu epidemii !!! Nieodpowiedzialne w obliczu zagrożenia [Tourism is the main cause of such a rapid spread of the virus so it should have been blocked already in January, but greedy governments afraid of losing their income did nothing and now brought about more serious losses - I'm wondering who will be held responsible for it after the epidemic is over!!! It's irresponsible in view of the threat.]

(43) Jak się zastanowić, to za tempo i skalę obecnej epidemii odpowiadaja glównie ludzie, którzy nie moga usiedzieć na miejscu, nawet kilka razy w roku musza się poniewierać $w$ jakichś zagranicznych zbiorowych noclegowniach - hotelach, pensjonatach, kurortach narciarskich. Zaliczać obiekty turystyczne macane przez miliony turystów, brudne zautki, plaże, targowiska. [If you think about it, the pace and scale of the current epidemic has been due to people who can't sit in one place, who even a few times a year have to roam around and stay in some shared accommodation abroad hotels, guesthouses, ski resorts. Visit tourist attractions touched by millions of tourists, dirty places, beaches, marketplaces...]

(44) turystyka $w$ dobie epidemi nie ma szans przetrwania pod rzadnym pozorem to przez wasza dzialalnosc tyle teraz mamy syfu w Polsce bo zawsze ryzykowaliscie $i$ graliście życiem ludzkim $w$ celu uzyskania korzysci majatkowych tak bylo zawsze ze wysylaliscie ludzi $w$ rejony gdzie bylo zagrozenie tereorystyczne kiedys teraz epidemiologiczne i przywlekliscie syfa do Polski. [tourism in time of pandemic has no chance to survive under any circumstances it is because of your activity that we have so much virus shit in Poland because you have always risked people's lives in order to gain 
financial benefits it has always been like that you sent people to the regions with a terrorist threat in the past now epidemiological threat bringing this virus shit to Poland.]

Finally, the topos of advantage is also used to underline benefits of halting tourism, understood as sending people abroad, for "us" and "our" country. It is used together with the topos of finances $[47,48]$ but one can also notice national pride undertones $[45,46]$. The latter also indicates that tourism is, by some commenters at least, associated only with sending people abroad.

(45) Może ludzie w końcu docenia piękno polski. [Maybe people will finally appreciate the beauty of Poland.]

(46) Polska jest piękna.Trzeba Polske zwiedzić. [Poland is beautiful. You should visit Poland.]

(47) Ekonomicznie to jest pozytywne dla nas więcej pieniędzy tak potrzebnych tu na inwestycje zostanie w kraju. [Economically this is good for us more money necessary for investment here will remain in the country.]

(48) skonczy sie wywozenie przez lemingow ciezko wypracowanych przez zwyklych skoncza sie zagraniczne wojaze lemingow. [lemmings will no longer take abroad the money earned by ordinary people, lemmings will no longer travel abroad.]

Example [48], with its animal metaphor TOURISTS ARE LEMMINGS, is important from the point of view of axiological proximization and what we might call "socially disuniting potential". The term lemingi ('lemmings') comes from rodents which according to a longstanding myth are driven to commit mass suicide. A video game titled "Lemmings" released in 1991, in which the player must save such creatures, further popularized the myth. According to Biesaga (2017) the word was first used with reference to people in 2007, while Janicki and Władyka (2012) point to 2008 when Internet users with right-wing political views used it with reference to career-oriented individuals with a university degree, a consumerist lifestyle and liberal political views. Even though Łaziński (2012) does not consider the metaphor offensive, it has usually served to express irony and criticism. In one of his articles published in a conservative monthly, Uważam Rze, Mazurek (2012) lists a number of attributes associated with "lemmings", including using Facebook and TVN24 (channel of a private broadcaster with liberal ideology) as their main source of knowledge, criticism of conservative values represented by their parents and grandparents, a general consumerist attitude, and "showing off". Again, we have here an opposition between "real", traditional Poles spending their holidays in their own country and "lemmings" fascinated with Western culture and lifestyle and spending "Polish" money abroad while enjoying expensive holidays that the "real" Poles cannot afford. With the polarization of society into PiS (Law and Justice) and PO (Civic Platform) supporters, "lemmings" have been associated with the latter. So have "wealthy" professionals from the tourism industry. 
Such an association is visible in other comments [49-53]:

(49) niech ida do PO-pewnie im da. [They should go to PO which will surely give them the money.]

(50) Kołobrzeg to ostoja totalnej opozycji. Jeszcze nie ma sezonu a im już mało. Niech występują o pomoc do Tuska i Brukseli. To ich bogowie. [Kołobrzeg is the refuge of total opposition. They should ask Tusk and Brussels for help. These are their gods.]

(51) Te beszczelne typy z POskomuny niech uzyja swoje milionowe nielegalne tzw. oszczędności a nie znowu z tapami po cudze. [These POstcommunist impertinent guys should use their illegal so-called savings worth millions instead of holding out for someone else's money.]

(52) Wygracie wybory to bedziecie sobie wyplacac, mieliscie juz swoich Boossow z Wybrzeza : Walesa, Tusk,Dulkiewicz czy jak jej tam ktorzy sprzedali wasze stocznie, wasz przemysl, nawet wodociagi i scieki niemcom. [Once you win elections you will get the money, you have already had your bosses from the Coast: Walesa, Tusk, Dulkiewicz or whatever she's called who sold your shipyards, your industry, even water pipes and sewage to Germans.]

(53) Upadajcie.Pa pa. PS.Niech Wam PO pomoże. [Go bankrupt. Bye-bye. PS. PO should help you.]

As can be seen in the above comments, the tourism industry representatives are referred to as "postcommunists". Often a play on words is used to combine both the name of the party (Civic Platform - PO) and "postcommunists" with reference to this group. As argued by Kłosińska and Rusinek (2019: 206-207), in the rhetoric of "good change" the term has a polarizing and accusatory function. "Postcommunists" arguably intend to destroy everything that the Law and Justice party along with their "good change" programme want to implement, according to their principles, to cherish Polish national tradition and to create a political system which will guarantee dignity and stable existence for Polish citizens. Placed in opposition to this programme, the tourism industry is seen as not catering for the needs of ordinary Poles and offering services many of these Poles cannot afford.

\section{Discussion and conclusions}

The Covid-19 pandemic has had a significant impact not only on public health but also on the global economy, along with many aspects of social life. The tourism industry has been hit hard by coronavirus lockdowns and travel restrictions, finding itself on the brink of unprecedented crisis. The objective behind the present article has been to examine the public response to calls for government financial help coming from that sector in Poland. To this end we have focused on online discourses revolving around the crisis in the tourism industry, working on the assumption that they will both reflect people's perceptions of professionals working in it and co-construct the crisis within collective consciousness. While limited in its 
scope, the analysis has provided some interesting insights as regards perceptions of tourism itself, the role of this branch in the country's economy as well as stereotypical representations of those who work in it.

Public online response to pleas for help coming from tourism professionals has been overwhelmingly hostile and negative, which, as we have argued, can be attributed to three factors, namely perceptions of how tourism-related businesses work, sociocultural factors including emotionality patterns characteristic for Polish people, and "the techno-discursive design" of the online media. The analysis of data clearly demonstrates that public understanding of industry dynamics is far from comprehensive. Referring to tour guides, travel agencies and hotel owners as well as bar owners at the Polish seaside selling fish and chips, commenters base their generalizations on personal experience. Even though in 2019 the Polish tourism industry was said to contribute $6 \%$ to GDP and provide employment for over 700000 people, it is by many commenters assessed negatively and seen as "parasitic" on Polish society. The fact that prices in tourism-related services (especially those concerning outbound tourism) are high has two consequences when it comes to perceptions of this sector. Firstly, it is a simplification (visible in the comments) that high prices of services translate into high income for those who provide these services. Examples of expensive cars and other luxurious goods given by commenters to illustrate this claim act as epistemic and axiological proximization triggers, and so do other stereotypical representations associated with the industry. Secondly, this fact leads to anger and envy on the part of those who cannot afford such services. Why should the existence of the sector they cannot benefit from be justified? Furthermore, the work of the tourist industry professionals is considered neither hard nor particularly skilled, as at first glance it is not associated with physical labour seen as an indicator of hard work. While trips abroad are frequently part and parcel of a tourism professionals' job, they are seen by others as holiday-time activities. We thus see a discursively constructed opposition between hard physical labour and something which is stereotypically perceived as an enjoyable way of spending time, often in distant exotic places. Finally, there is a stereotype rooted in the Polish collective mentality that financial success is often the result of fraudulent and unfair practices involving the exploitation of others or, at least, of the system (the topos of abuse).

Socio-political polarization, creating a conducive environment for incivility, also clearly reverberates in the online discourses we studied. "Us" vs "them", with a dividing line along political affiliations, encompasses various groups and individuals. We thus have opposition and tensions between "the elites" and the rest of society that includes "ordinary Poles". It is the latter that are associated with Polish values, tradition, and often also with hard physical labour. Tourism industry professionals are considered to both belong to, and cater for the former group. While such an opposition is not only reflected in various public discourses, including those we studied (constituted nature of discourse), it is also discursively constructed, amplified and perpetuated by political, mainstream and social media discourses, and thus likely to affect the perceptions of society members 
(constitutive nature of discourse). As demonstrated in research on other situations involving physical or symbolic threats as well as scarcity of resources, the tendency to create in- and out-groups is naturally enhanced (see Larina et al. 2019). The "Other" that is either demonized or denigrated evokes anger along with other negative emotions (see Lewandowska-Tomaszczyk 2020). We have to remember that tourism industry professionals are just one of many other groups in Poland targeted by discourses of hostility during the time of pandemic-triggered crisis (including healthcare workers and police officers).

The "techno-discursive design" of the online media enables, facilitates and amplifies both polarization and incivility (see KhosraviNik 2017b, 2018, Kopytowska forthcoming). Connectivity and interactivity enabled by the Internet have made it possible for people to satisfy their "compulsion for proximity", which has become particularly relevant in a time of lockdowns and social distancing, when online interactions compensate for the lack of offline contact. At the same time, however, cyberspace has become the platform where people have the opportunity to alleviate frustrations arising from feelings of threat and insecurity. This platform has also made it possible for people with similar fears and "axiological preferences" to connect (spatio-temporal proximization) and further enhance and perpetuate their judgements and emotions (axiological and emotional proximization) (Kopytowska 2017, forthcoming). As already mentioned, strong emotions of anger and disgust (Lewandowska-Tomaszczyk 2017c) make people more likely to resort to stereotypical thinking. So does lack of accountability resulting from anonymity. Not surprisingly, then, we find in our data stereotypes and simplistic judgements, frequently leading to sweeping generalizations. Anonymity, enhancing stronger ingroup identity has also contributed to greater polarization and, in consequence, incivility towards others.

As we have argued, with its potential to transgress time and space boundaries, the Internet has in important ways transformed travel practices, as well as perceptions of places and "others". Despite many positive implications of this transformation process, including social media activism intended to support the tourism industry in diverse ways, it has also meant creating a conducive environment for the spread of both harmful stereotypes concerning various elements of this industry and incivility targeting groups and individuals. Representational and interpersonal dimensions of proximization have thus meant providing us, media users, with opportunities for co-constructing social reality, involving both solidarity and disunity dynamics. They have also considerably transformed "the tourist gaze" taking it to a new mediated level.

(C) Monika Kopytowska and Radosław Krakowiak, 2020 cccreative

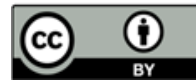

This work is licensed under a Creative Commons Attribution 4.0 International License https://creativecommons.org/licenses/by/4.0/ 


\section{REFERENCES}

Baider, Fabienne \& Monika Kopytowska. 2017. Conceptualising the Other: Online discourses on the current refugee crisis in Cyprus and in Poland. Lodz Papers in Pragmatics 13 (2). 203-233. DOI: https://doi.org/10.1515/lpp-2017-0011

Beauregard, Guy. 1999. Travelling Stereotypes: "The Japanese Tourist" in Canada. Journal of Transnational \& Crosscultural Studies 7 (1). 79-95.

Berger, Peter \& Thomas Luckmann.1991 [1966]. The social construction of reality. A treatise in the sociology of knowledge. London: Penguin Books.

Biesaga, Monika. 2016. Drugie życie leminga we współczesnej polszczyźnie. Polonica XXXVI (36). 43-54.

Boden, Deirdre \& Harvey L. Molotch. 1994. The compulsion of proximity. In Roger Friedland \& Deirdre Boden (eds.), NowHere: Space, time, and modernity, 257-286. Berkeley: University of California Press.

Cap, Piotr. 2006. Legitimisation in political discourse: a cross-disciplinary perspective on the modern US war rhetoric. Newcastle: Cambridge Scholars Press.

Cap, Piotr. 2008. Towards the proximization model of the analysis of legitimization in political discourse. Journal of Pragmatics 40. 17-41.

Cap, Piotr. 2010. Axiological aspects of proximization. Journal of Pragmatics 42. 392-407.

Cap, Piotr. 2013. Proximization: the pragmatics of symbolic distance crossing. Amsterdam: Benjamins.

Cap, Piotr. 2017. The Language of Fear: Communicating Threat in Public Discourse. London and New York: Palgrave Macmillan.

Cap, Piotr. 2018a. "We don't want any immigrants or terrorists here": The linguistic manufacturing of xenophobia in the post-2015 Poland. Discourse \& Society 29 (4). 380398.

Cap, Piotr. 2018b. From "cultural unbelonging" to "terrorist risk": communicating threat in the Polish anti-immigration discourse. Critical Discourse Studies 15 (3). 285-302.

Chilton, Paul. 2004. Analysing political discourse: theory and practice. London: Routledge.

Chilton, Paul. 2005. Discourse Space Theory: geometry, brain and shifting viewpoints. Annual Review of Cognitive Linguistics 3. 78-116.

Chilton, Paul. 2010. From mind to grammar: coordinate systems, prepositions, constructions. In Vyvyan Evans \& P. Chilton (eds.), Language, Cognition and space: the state of the art and new directions, 499-514. London: Equinox.

Chilton, Paul. 2014. Language, space and mind: the conceptual geometry of linguistic meaning. Cambridge: Cambridge University Press.

Dube Kaitano, Godwell Nhamo \& David Chikodzi. 2020. COVID-19 cripples global restaurant and hospitality industry. Current Issues in Tourism. DOI: 10.1080/13683500.2020.1773416

Duckitt, John. 2006. Differential effects of right wing authoritarianism and social dominance orientation on outgroup attitudes and their mediation by threat from and competitiveness to outgroups. Personality and Social Psychology Bulletin 32. 684-696.

Fairclough, Norman \& Ruth Wodak. 1997. Critical discourse analysis. In Teun A. van Dijk (ed.), Discourse as social interaction, 14-31. London: Sage.

Feifer, Maxine. 1985. Going Places. London: Macmillan.

Gursoy, Dogan \& Christina G. Chi. 2020. Effects of COVID-19 Pandemic on Hospitality Industry: Review of the Current Situations and a Research Agenda. Journal of Hospitality Marketing \& Management 29 (5). 527-29. DOI: 10.1080/19368623.2020.1788231

Halpern, Daniel \& Jennifer Gibbs. 2013. Social media as a catalyst for online deliberation? Exploring the affordances of Facebook and YouTube for political expression. Computers in Human Behavior 29 (3). 1159-1168. 
Hammett, Daniel. 2014. Tourism Images and British Media Representations of South Africa. Tourism Geographies 16 (2). 221-36. DOI: 10.1080/14616688.2012.762688

Hardaker, Claire \& Mark McGlashan 2015. 'Real men don't hate women': Twitter rape threats and group identity. Journal of Pragmatics 91. 81-93.

Hart, Christopher. 2010. Critical Discourse Analysis and cognitive science: new perspectives on immigration discourse. Basingstoke: Palgrave.

Hepp, Andreas. 2013. Cultures of mediatization. Cambridge: Polity Press.

Hutchby, Ian. 2001. Technolgies, texts, and affordances. Sociology 35 (2). 441-456.

Janicki, Mariusz \& Wiesław Władyka. 2012. Strategia leminga. www.polityka.pl Retrieved from: https:/www.polityka.pl/tygodnikpolityka/kraj/1528687,1,kim-jest-polityczny-leming.read

Jun, Jungmi \& Kyeung Mi Oh. 2015. Framing Risks and Benefits of Medical Tourism: A Content Analysis of Medical Tourism Coverage in Korean American Community Newspapers. Journal of Health Communication 20 (6). 720-27. DOI: 10.1080/10810730.2015.1018574

KhosraviNik, Majid. 2014. Critical discourse analysis, power and new media discourse. In Yusuf Kalyango \& Monika Kopytowska (eds.), Why Discourse Matters: Negotiating Identity in the Mediatized World, 287-306. New York: Peter Lang.

KhosraviNik, Majid. 2017a. Right wing populism in the West: Social Media Discourse and Echo Chambers. Insight Turkey 19 (3). 53-68.

KhosraviNik, Majid. 2017b. Social Media Critical Discourse Studies (SM-CDS)." In John Flowerdew \& John E. Richardson (eds.), Handbook of Critical Discourse Analysis, 583-596. London: Routledge.

KhosraviNik, Majid. 2018. Social Media Techno-Discursive Design, Affective Communication and Contemporary Politics. Fudan Journal of the Humanities and Social Sciences 11. 427-442.

KhosraviNik, Majid \& Johann Unger. 2016. Critical discourse studies and social media: Power, resistance and critique in changing media ecologies. In Ruth Wodak \& Michael Meyers (eds.), Methods of critical discourse studies, 3rd ed, 205-233. London: Sage.

KhosraviNik Majid \& Eleonora Esposito. 2018. Online hate, digital discourse and critique: Exploring digitally-mediated discursive practices of gender-based hostility. Lodz Papers in Pragmatics 14 (1). 45-58.

Kilgarriff, Adam, Vit Baisa, Jan Bušta, Milos Jakubícek, Vojtech Kovář, Jan Michelfeit, Pavel Rychlý \& Vit Suchomel. 2014. The Sketch Engine: ten years on. Lexicography 1 (1). 7-36.

Kłosińska, Katarzyna \& Michał Rusinek. 2019. Dobra zmiana, czyli jak rządzi się światem za pomoca stów. Kraków: Wydawnictwo Znak.

Kopytowska, Monika. 2013. Blogging as the mediatization of politics and a new form of social interaction - a case study of Polish and British political blogs. In Piotr Cap \& Urszula Okulska (eds.), Analyzing Genres in Political Communication, 379-421. Amsterdam: John Benjamins.

Kopytowska, Monika. 2014. Pictures in our heads: Crisis, conflict, and drama. In Yusuf Kalyango \& Monika Kopytowska (eds.), Why Discourse Matters: Negotiating Identity in the Mediatized World, 89-109. New York: Peter Lang.

Kopytowska, Monika. 2015a. Mediating identity, ideology and values in the public sphere: Towards a new model of (constructed) social reality. Lodz Papers in Pragmatics 11 (2). 133-156. DOI: https://doi.org/10.1515/lpp-2015-0008

Kopytowska, Monika. 2015b. Ideology of 'here' and 'now'. Critical Discourse Studies 12 (3). 347-365. DOI: https://doi.org/10.1080/17405904.2015.1013485

Kopytowska, Monika. 2015c. Covering conflict: between universality and cultural specificity in news discourse genre and journalistic style. International Review of Pragmatics 
(Special Issue on Communicative styles and genres: between universality and culturespecificity) 7. 308-339.

Kopytowska, Monika. 2017. Introduction: Discourses of Hate and Radicalism in Action. In Monika Kopytowska (ed.), Contemporary Discourses of Hate and Radicalism across Space and Genres, 1-12. Amsterdam: John Benjamins.

Kopytowska, Monika. 2018a. The televisualization of ritual: spirituality, spatiality and copresence in religious broadcasting. In Paul Chilton \& Monika Kopytowska (eds.), Religion, Language and Human Mind, 437-473. New York: Oxford University Press.

Kopytowska, Monika. 2018b. Culture, Mediated Experience and the Semiotics of Distance. In Artur Gałkowski \& Monika Kopytowska (eds.), Current Perspectives in Semiotics: Signs, Signification and Communication, 221-234. Frankfurt: Peter Lang.

Kopytowska, Monika. Forthcoming. "Proximization, prosumption and salience in digital discourse: on the interface of social media communicative dynamics and the spread of populist ideologies." [Special Issue on Social Media Critical Discourse Studies]. Critical Discourse Studies. DOI: 10.1080/17405904.2020.1842774

Kopytowska, Monika, Julita Woźniak \& Łukasz Grabowski. 2017. "From 'patriotism' to hate: axiological urgency in online comments related to refugees". In Stavros Assimakopoulos, Fabienne H. Baider \& Sharon Millar (eds.), Online Hate Speech in the European Union: A Discourse-Analytic Perspective, 42-51. Berlin: Springer.

Kopytowska, Monika, Łukasz Grabowski \& Julita Woźniak. 2017. "Mobilizing against the Other: Cyberhate, refugee crisis and proximization". In Monika Kopytowska (ed.), Contemporary Discourses of Hate and Radicalism across Space and Genres, 57-97.

Lapointe, Dominic. 2020. Reconnecting Tourism after COVID-19: The Paradox of Alterity in Tourism Areas. Tourism Geographies 22 (3). 633-38. DOI: 10.1080/14616688.2020.1762115.

Larina, Tatiana, Vladimir Ozyumenko \& Douglas Mark Ponton. 2019. Persuasion strategies in media discourse about Russia: Linguistic ambiguity and uncertainty. Lodz Papers in Pragmatics 15 (1). 3-22. DOI: https://doi.org/10.1515/lpp-2019-0002

Lea, Martin \& Russel Spears. 1991. Computer-mediated communication, de-individuation and group decision-making. International Journal of Man Machine Studies 34. 283-301.

Lenzen, Manfred, Mengyu Li, Arunima Malik, Francesco Pomponi, Ya-Yen Sun, Thomas Wiedmann \& Futu Faturay. 2020. Global Socio-Economic Losses and Environmental Gains from the Coronavirus Pandemic. PLoS ONE 15 (7). 1-13. DOI: 10.1371/journal.pone.0235654.

Lew, Alan A., Joseph M. Cheer, Michael Haywood, Patrick Brouder \& Noel B. Salazar. 2020. Visions of travel and tourism after the global COVID-19 transformation of 2020. Tourism Geographies 22(3). 455-466. DOI: 10.1080/14616688.2020.1770326

Lewandowska-Tomaszczyk, Barbara. 2013. Online Interconnectivity and Negative Emotion Patterning. Sociedad de la Información 44. 76-109.

Lewandowska-Tomaszczyk, Barbara. 2015. Emergent group identity construal in online discussions: A linguistic perspective. In F. Zeller, C. Ponte \& B. O’Neill (eds.), Revitalising Audience Research: Innovations in European Audience Research, 80-105. New York: Routledge.

Lewandowska-Tomaszczyk, Barbara. 2017a. Identity, Emotions and Cultural Differences in English and Polish Online Comments. International Journal of Language and Culture 4 (1). 47-71. DOI: https://doi.org/10.1075/ijolc.4.1.04lew

Lewandowska-Tomaszczyk, Barbara. 2017b. Conflict Radicalization and Emotions in English and Polish Online Discourses on Immigration and Refugees. In Stephen Croucher, Barbara Lewandowska-Tomaszczyk \& Paul A. Wilson (eds.), Conflict, Mediated Message and Group Dynamics: Intersections of Communication, 1-24. USA: Rowman \& Littlefield.

Lewandowska-Tomaszczyk, Barbara. 2017c. Incivility and confrontation in online conflict discourses. Lodz Papers in Pragmatics 13 (2). 347-367. DOI: https://doi.org/10.1075/ps.18069.lew 
Lewandowska-Tomaszczyk, Barbara. 2020. Culture-driven emotional profiles and online discourse extremism. Pragmatics and Society 11 (2). 262-291. DOI: https://doi.org/ $10.1075 /$ ps.18069.lew

Lewandowska-Tomaszczyk, Barbara \& Paul A. Wilson. 2013. English Fear and Polish Strach in Contrast: GRID Approach and Cognitive Corpus Linguistic Methodology. In Jimmy Fontaine, Klaus R. Scherer \& Cristina Soriano (eds.), Components of Emotional Meaning: A Sourcebook, 425-436. Oxford: Oxford University Press.

Lewandowska-Tomaszczyk, Barbara \& Paul A. Wilson. 2014. Self-conscious Emotions in Collectivistic and Individualistic Cultures: A Contrastive Linguistic Perspective. In Jesús Romero-Trillo (ed.), Yearbook of Corpus Linguistics and Pragmatics vol. 2: New Empirical and Theoretical Paradigms, 123-148. Berlin: Springer.

Lewandowska-Tomaszczyk, Barbara \& Paul A. Wilson. 2016. Physical and Moral Disgust with Socially Believable Behaving Systems in Different Cultures. In Anna Esposito \& Lakhmi C. Jain (eds.), Toward Robotic Socially Believable Behaving Systems, Volume I Modelling of Emotions, 105-132. Cham: Springer. DOI: https://doi.org/10.1007/978-3319-31056-5_7

Mazurek, Robert. 2012. Alfabet leminga. uwazamrze.pl Retrieved from: http://www.old.uwazamrze.pl/artykul/909451/alfabet-leminga/3

Murti, Desideria C. W. 2020. Gaze the Struggle of Others: The Representations of Rural Places and People of Indonesia in Tourism Media for Australian Tourists. Journal of Communication Inquiry 44 (3). 231-55. DOI: 10.1177/0196859920901326.

Musolff, Andreas. 2014. Metaphorical parasites and "parasitic" metaphors: Semantic exchanges between political and scientific vocabularies. Journal of Language and Politics 13 (2). 218-233

O’Regan, Michael, Jaeyeon Choe \& Michael Di Giovine. 2019. Reframing and Reconceptualising Gambling Tourism in Macau as a Chinese Pilgrimage. Tourism Geographies 21 (3). 508-28. DOI: 10.1080/14616688.2018.1545248.

Pasquinelli, Cecilia \& Mariapina Trunfio. 2020. Overtouristified Cities: An Online News Media Narrative Analysis. Journal of Sustainable Tourism 28 (11). 1805-1824. DOI: 10.1080/09669582.2020.1760871.

Postmes, Tom, Russel Spears \& Martin Lea. 2002. Intergroup differentiation in computermediated communication: Effects of depersonalization. Group Dynamics 6 (1). 3-16.

Reisigl, Martin \& Ruth Wodak. 2001. Discourse and discrimination. London: Routledge.

Santana, Arthur D. 2014. Virtuous or Vitriolic. Journalism Practice 8 (1). 18-33.

Searle, John. 1995. The construction of social reality. London: The Penguin.

Searle, John. 2006. Social ontology: some basic principles. Anthropological Theory 6 (1). $12-29$.

Searle, John. 2010. Making the social world: the structure of human civilization. Oxford: Oxford University Press.

Shakeela, Aishath \& David Weaver. 2014. The Exploratory Social-Mediatized Gaze: Reactions of Virtual Tourists to an Inflammatory YouTube Incident. Journal of Travel Research 55 (1). 113-124. DOI: https://doi.org/10.1177/0047287514532369

Tadic, Bosljka, Vladimir, Gligorijevic, Marija Mitrovic \& Milovan Suvakov. 2013. Co-evolutionary mechanisms of emotional bursts in online social dynamics and networks. Entropy 15. 5084-5120.

Tetlock, Philip E. 1983. Accountability and judgment processes in a personality prediction task. Journal of Personality and Social Psychology 45 (1). 74-83.

Tice, Dianne M., Ellen Bratslavsky \& Roy F. Baumeister. 2001. Emotional distress regulation takes precedence over impulse control. Personality and Social Psychology 80 (1). 53-67. 
Tomassini, Lucia \& Elena Cavagnaro. 2020. The Novel Spaces and Power-Geometries in Tourism and Hospitality after 2020 Will Belong to the 'Local.' Tourism Geographies 22(3). 713-19. DOI: 10.1080/14616688.2020.1757747.

Urry, John. 1990. The Tourist Gaze. London: Sage.

Urry, John. 1995. Consuming places. London: Routledge.

Urry, John. 2002. Mobility and proximity. Sociology 36 (2). 255-274.

Wen, Jun, Joshua Aston, Xinyi Liu \& Tianyu Ying. 2020. Effects of Misleading Media Coverage on Public Health Crisis: A Case of the 2019 Novel Coronavirus Outbreak in China. Anatolia: An International Journal of Tourism \& Hospitality Research 31 (2). 331-336. DOI: 10.1080/13032917.2020.1730621

Zhang, Yunpeng \& Fang Xu. 2020. Ignorance, Orientalism and Sinophobia in Knowledge Production on COVID-19. Tijdschrift Voor Economische En Sociale Geografie (Journal of Economic \& Social Geography) 111 (3). 211-223. doi: 10.1111/tesg.12441

Zhao, Zhao, Minmin Zhu \& Xiaofei Hao. 2018. Share the Gaze: Representation of Destination Image on the Chinese Social Platform WeChat Moments. Journal of Travel \& Tourism Marketing 35 (6). 726-739. DOI: 10.1080/10548408.2018.1432449

\section{Appendix 1}

\begin{tabular}{|c|c|c|}
\hline Headline & Date & Link \\
\hline $\begin{array}{l}\text { Koronawirus. Możliwe zwroty za } \\
\text { imprezy turystyczne. ['Coronavirus. } \\
\text { Possible refunds for tourist events'.] }\end{array}$ & $\begin{array}{l}6 \text { March } \\
2020\end{array}$ & $\begin{array}{l}\text { https://niezalezna.pl/314716- } \\
\text { koronawirus-mozliwe-zwroty- } \\
\text { za-imprezy-turystyczne }\end{array}$ \\
\hline $\begin{array}{l}\text { Rz: Koronawirus zabija turystykę w } \\
\text { Polsce. } \\
\text { ['Coronavirus kills tourism industry } \\
\text { in Poland'.] }\end{array}$ & $\begin{array}{l}6 \text { March } \\
2020\end{array}$ & $\begin{array}{l}\text { https://www.dorzeczy.pl/kraj/131777/ } \\
\text { rz-koronawirus-zabija-turystyke-w- } \\
\text { polsce.html }\end{array}$ \\
\hline $\begin{array}{l}\text { Czy koronawirus uderzy w branżę } \\
\text { turystyczną w Małopolsce? ['Will } \\
\text { coronavirus hit tourism industry in } \\
\text { Malopolska?'] }\end{array}$ & $\begin{array}{l}9 \text { March } \\
2020\end{array}$ & $\begin{array}{l}\text { https://gazetakrakowska.pl/czy- } \\
\text { koronawirus-uderzy-w-branze- } \\
\text { turystyczna-w-malopolsce/ar/ } \\
\text { c14-14845546 }\end{array}$ \\
\hline $\begin{array}{l}\text { Koronawirus w Krakowie. Zanika } \\
\text { turystyka pod Wawelem. Biura } \\
\text { podróży na skraju bankructwa. } \\
\text { ['Coronavirus in Cracow. Tourism } \\
\text { near Wawel disappears. Travel } \\
\text { agencies on the brink of } \\
\text { bankruptcy'.] }\end{array}$ & $\begin{array}{l}13 \text { March } \\
2020\end{array}$ & $\begin{array}{l}\text { https://gazetakrakowska.pl/koronawiru } \\
\text { s-w-krakowie-zanika-turystyka-pod- } \\
\text { wawelem-biura-podrozy-na-skraju- } \\
\text { bankructwa/ar/c1-14856615Asdasdasd }\end{array}$ \\
\hline $\begin{array}{l}\text { Hotelarze z Kołobrzegu chca pomocy } \\
\text { państwa. ['Hotel owners from } \\
\text { Kołobrzeg demand government aid'] }\end{array}$ & $\begin{array}{l}16 \text { March } \\
2020\end{array}$ & $\begin{array}{l}\text { https://niezalezna.pl/316691-hotelarze- } \\
\text { z-kolobrzegu-chca-pomocy-panstwa }\end{array}$ \\
\hline $\begin{array}{l}\text { Turystyka na OIOM-ie } \\
\text { ['Tourism in ICU'] }\end{array}$ & 22 March & $\begin{array}{l}\text { https://www.dorzeczy.pl/kraj/133591/ } \\
\text { turystyka-na-oiom-ie.html }\end{array}$ \\
\hline
\end{tabular}




\begin{tabular}{|c|c|c|}
\hline Headline & Date & Link \\
\hline $\begin{array}{l}\text { Minister Emilewicz-zdradza: „Rząd } \\
\text { pracuje nad programem } 1000 \text { plus”. } \\
\text { Ma dotyczyć turystyki i rekreacji. } \\
\text { ['Minister Emilewicz reveals: “The } \\
\text { government is working on the } 1000 \\
\text { plus programme”. It will concern } \\
\text { tourism and leisure'] }\end{array}$ & $\begin{array}{c}2 \text { April } \\
2020\end{array}$ & $\begin{array}{l}\text { https://niezalezna.pl/320406-minister- } \\
\text { emilewicz-zdradza-rzad-pracuje-nad- } \\
\text { programem-1000-plus-ma-dotyczyc- } \\
\text { tyrustyki-i-rekreacji }\end{array}$ \\
\hline $\begin{array}{l}\text { 1. Sztab kryzysowy dla turystyki. } \\
\text { Ministerstwo przygotowuje pakiet } \\
\text { pomocy dla branży. } \\
\text { 2. ['Emergency meeting for tourism. } \\
\text { Ministry prepares aid package for } \\
\text { industry'] }\end{array}$ & $\begin{array}{l}9 \text { March } \\
2020\end{array}$ & $\begin{array}{l}\text { https://www.money.pl/gospodarka/ } \\
\text { sztab-kryzysowy-dla-turystyki- } \\
\text { ministerstwo-przygotowuje-pakiet- } \\
\text { pomocy-dla-branzy- } \\
6487161321990273 \text { a.html }\end{array}$ \\
\hline $\begin{array}{l}\text { We wtorek koronawirusowy pakiet } \\
\text { dla polskiej turystyki. } \\
\text { ['Covid package for Polish tourism } \\
\text { industry on } \\
\text { Tuesday '] }\end{array}$ & $\begin{array}{l}9 \text { March } \\
2020\end{array}$ & $\begin{array}{l}\text { https://wgospodarce.pl/informacje/ } \\
\text { 76378-we-wtorek-koronawirusowy- } \\
\text { pakiet-dla-polskiej-turystyki }\end{array}$ \\
\hline $\begin{array}{l}\text { 3. Już } 400 \text { mln strat w samej } \\
\text { turystyce przez koronawirusa } \\
\text { 4. ['400 million losses in tourism } \\
\text { industry because of coronavirus'] }\end{array}$ & $\begin{array}{l}7 \text { March } \\
2020\end{array}$ & $\begin{array}{l}\text { 1. https://wyborcza.pl/7,155287,25767 } \\
\text { 097,juz-400-mln-strat-w-samej- } \\
\text { turystyce-przez-koronawirusa.html }\end{array}$ \\
\hline $\begin{array}{l}\text { Polska turystyka traci na epidemii } \\
400 \mathrm{mln} \text { zł } \\
\text { ['Polish tourism industry loses } 400 \\
\text { million because of epidemic'] }\end{array}$ & $\begin{array}{l}7 \text { March } \\
2020\end{array}$ & $\begin{array}{l}\text { https://wgospodarce.pl/informacje/763 } \\
\text { 06-polska-turystyka-traci-na-epidemii- } \\
\text { 400-mln-zl }\end{array}$ \\
\hline $\begin{array}{l}\text { "Rzeczpospolita": Wirus bije w } \\
\text { turystykę. } \\
\text { [“"Rzeczpospolita": Virus hits } \\
\text { tourism'.] }\end{array}$ & $\begin{array}{l}6 \text { March } \\
2020\end{array}$ & $\begin{array}{l}\text { https://wydarzenia.interia.pl/raporty/ra } \\
\text { port-koronawirus-chiny/aktualnosci// } \\
\text { news-rzeczpospolita-wirus-bije-w- } \\
\text { turystyke,nId,4365854\#comments4-1 }\end{array}$ \\
\hline $\begin{array}{l}\text { 5. Kryzys w branży turystycznej. } \\
\text { "To jest dramat" } \\
\text { ["Crisis in tourism industry. } \\
\text { "This is a disaster"] }\end{array}$ & $\begin{array}{l}13 \text { March } \\
2020\end{array}$ & $\begin{array}{l}\text { https://lovekrakow.pl/aktualnosci/ } \\
\text { kryzys-w-branzy-turystycznej-to-jest- } \\
\text { dramat_34683.html }\end{array}$ \\
\hline $\begin{array}{l}\text { 6. Ogromne straty w branży } \\
\text { turystycznej przez koronawirusa. } \\
\text { Liczone będą w miliardach dolarów. } \\
\text { 7. ['Huge losses in tourism industry } \\
\text { caused by coronavirus. They will } \\
\text { amount to billions of dollars'.] }\end{array}$ & $\begin{array}{l}9 \text { March } \\
2020\end{array}$ & $\begin{array}{l}\text { https://niezalezna.pl/315022-ogromne- } \\
\text { straty-w-branzy-turystycznej- } \\
\text { przez-koronawirusa-liczone-beda- } \\
\text { w-miliardach-dolarow }\end{array}$ \\
\hline $\begin{array}{l}\text { Branża turystyczna czeka na rządową } \\
\text { pomoc. } \\
\text { ['Tourism industry waits for } \\
\text { government aid'.] }\end{array}$ & $\begin{array}{c}24 \text { March } \\
2020\end{array}$ & $\begin{array}{l}\text { https://biznes.interia.pl/gospodarka/ } \\
\text { news-branza-turystyczna-czeka- } \\
\text { na-rzadowa-pomoc,nId,4400172\# } \\
\text { comments4-1 }\end{array}$ \\
\hline
\end{tabular}




\begin{tabular}{|c|c|c|}
\hline Headline & Date & Link \\
\hline $\begin{array}{l}\text { Turystyka ucierpi pierwsza. } \\
\text { ['Tourism will be the first to suffer'.] }\end{array}$ & $\begin{array}{l}24 \text { March } \\
2020\end{array}$ & $\begin{array}{l}\text { https://biznes.interia.pl/gospodarka/ } \\
\text { news-turystyka-ucierpi-pierwsza,nId, } \\
\text { 4397997\#comments4-1dasdas }\end{array}$ \\
\hline $\begin{array}{l}\text { Spadki sprzedaży w branży } \\
\text { turystycznej sięgają } 60-70 \text { procent } \\
\text { ['Drop in sales in tourism industry } \\
\text { reaches } 60-70 \text { percent'.] }\end{array}$ & $\begin{array}{l}20 \text { March } \\
2020\end{array}$ & $\begin{array}{l}\text { https://biznes.interia.pl/gospodarka/ } \\
\text { news-spadki-sprzedazy-w-branzy- } \\
\text { turystycznej-siegaja-60-70-procent, } \\
\text { nId,4392625\#comments4-1 }\end{array}$ \\
\hline $\begin{array}{l}\text { 8. Branża turystyczna ma dość. } \\
\text { "Turystyka umiera, rząd nas nie } \\
\text { wspiera!" } \\
\text { 9. ['Tourism industry says enough. } \\
\text { "Tourism is dying and the } \\
\text { government isn't supporting us"'.] }\end{array}$ & $\begin{array}{l}23 \text { June } \\
2020\end{array}$ & $\begin{array}{l}\text { https://turystyka.wp.pl/branza- } \\
\text { turystyczna-ma-dosc-turystyka- } \\
\text { umiera-rzad-nas-nie-wspiera- } \\
6524681487047520 \mathrm{a}\end{array}$ \\
\hline $\begin{array}{l}\text { Biznes: Po słowach ministra wzrosła } \\
\text { liczba rezygnacji z wyjazdów. } \\
\text { ['Business: After Minister's } \\
\text { announcement the number of } \\
\text { cancelled trips has increased'.] }\end{array}$ & $\begin{array}{l}17 \text { April } \\
2020\end{array}$ & $\begin{array}{l}\text { https://biznes.interia.pl/gospodarka/ } \\
\text { news-biznes-po-slowach-ministra- } \\
\text { wzrosla-liczba-rezygnacji-z-wyjaz, } \\
\text { nId,4443477 }\end{array}$ \\
\hline $\begin{array}{l}\text { Dalsza pomoc dla turystyki wątpliwa. } \\
\text { ['Further aid for tourism is doubtful'] }\end{array}$ & $\begin{array}{l}9 \text { June } \\
2020\end{array}$ & $\begin{array}{l}\text { http://www.tur-info.pl/a/54188, } \\
\text { turystyka-ministerstwo-rozwoju- } \\
\text { granice.html }\end{array}$ \\
\hline $\begin{array}{l}\text { Promyk nadziei na pomoc dla } \\
\text { turystyki. } \\
\text { ['Ray of hope for tourism'.] }\end{array}$ & $\begin{array}{l}17 \text { June } \\
2020\end{array}$ & $\begin{array}{l}\text { http://www.tur-info.pl/a/56534, } \\
\text { minister-rozwoju-pomoc- } \\
\text { turystyka.html }\end{array}$ \\
\hline
\end{tabular}

\section{Article history:}

Received: 30 July 2020

Revised: 15 October 2020

Accepted: 18 October 2020

\section{История статьи:}

Дата поступления в редакцию: 30 июля 2020

Дата принятия к печати: 18 октября 2020

\section{Bionotes:}

Monika KOPYTOWSKA is Assistant Professor at the University of Lodz, the Department of Pragmatics. Her research interests revolve around media discourse and the pragma-rhetorical aspects of the mass-mediated representation of conflict, ethnicity, and religion. She has published internationally in linguistic journals and volumes (e.g. [ed.] Contemporary Discourses of Hate and Radicalism across Space and Genres, Benjamins, 2017, with Y. Kalyango [eds.] Languages, Cultures, Media, Université Savoie Mont Blanc, with C. Karner [eds.], National Identity and Europe in Times of Crisis, Emerald, 2017, with P. Chilton [eds.] Religion, Language and Human Mind. New York: Oxford University Press, 2018). She is the Editor-in-Chief of Lodz Papers in Pragmatics (De Gruyter). 


\section{Contact information:}

Institute of English Studies

Faculty of Philology

University of Lodz

Pomorska 171/173, 90-236 Lodz, Poland

e-mail: monika.kopytowska@uni.lodz.pl

ORCID ID: 0000-0002-1065-7044

Radosław KRAKOWIAK graduated from the Academy of Hospitality, Catering Industry and Tourism in Warsaw. Currently employed as MICE Director at "Impuls" Travel. He has worked in tourism industry since 1999 specializing in incentive travel and event management.

\section{Contact information:}

e-mail: radoslaw.krakowiak@wp.pl

\section{Сведения об авторах:}

Моника КОПЫТОВСКА - доцент кафедры прагматики Лодзинского университета, Польша. Область ее научных интересов - медиадискурс, прагмариторические аспекты освещения конфликтов, этничность и религия в СМИ. Является автором и соредактором ряда международных публикаций, среди которых: Contemporary Discourses of Hate and Radicalism across Space and Genres, Benjamins, 2017 (совместно с Y. Kalyango), Languages, Cultures, Media, Université Savoie Mont Blanc (совместно с C. Karner), National Identity and Europe in Times of Crisis, Emerald, 2017 (совместно с P. Chilton), Religion, Language and Human Mind. New York: Oxford University Press, 2018. Является главным редактором журнала Lodz Papers in Pragmatics (издательство De Gruyter).

\section{Контактная информация:}

Institute of English Studies

Faculty of Philology

University of Lodz

Pomorska 171/173, 90-236 Lodz, Poland

e-mail: monika.kopytowska@uni.lodz.pl

ORCID ID: 0000-0002-1065-7044

Радослав КРАКОВЯК окончил Варшавскую академию гостеприимства, общественного питания и туризма. Работает в сфере туризма с 1999 года. Специализируется на корпоративном туризме и организации мероприятий. В настоящее время директор по деловому туризму в компании «Импульс» Трэвел.

\section{Контактная информация:}

e-mail: radoslaw.krakowiak@wp.pl 